\title{
Comparative Study in Seed Yield and Flowers Attractivity to Bee Visitors Between Nigella Sativa L. and Nigella Damascena L. (Ranunculaceae) Grown Under Semiarid Conditions
}

\author{
Shahera Zaitoun ${ }^{*}$, Abd Al-Majeed Al-Ghzawi², Nezar Samarah², Ahmad Alqudah ${ }^{2}$ \\ ${ }^{1}$ Department of Plant Production and Protection, Faculty of Agricultural Technology, Al-Balqa' \\ Applied University, Al-Salt, Jordan \\ ${ }^{2}$ Department of Plant Production, Faculty of Agriculture, University of Science and Technology \\ P.O. Box 3030, Irbid, Jordan
}

Received: 14 January 2008. Accepted: 23 July 2008.

\begin{abstract}
This experiment was carried out during the growing season 2005 at the campus of Jordan University of Science and Technology ( $32^{\circ} 22^{\prime \prime} \mathrm{N}, 35^{\circ} 49^{\prime \prime}$ E), Jordan. Two different Nigella species were used in this experiment; Nigella sativa L. and Nigella damascena L. This study was aimed to identify the bee visitors of Nigella species and the pollination requirements of Nigella flowers grown under semiarid conditions. The results showed that flowers of both Nigella species were visited by seven different bee visitors. However, flowers of $N$. damascena were more attractive to bees than $N$. sativa flowers. $N$. damascena produced on average significantly higher plant, more number of branches per plant, more seed yield, total seed weight and higher number of capsules per plant. On the other hand, N. sativa produced its flowers and matured nearly two weeks earlier than $N$. damascena. There is no interaction between Nigel$l a$ species and pollination treatments for all yield parameter. $N$. damascena was higher in number of ovaries, seeds per capsules, seed set percentage, seeds per plant and total seed weight than $N$. sativa under treatments conditions. Also, flowers of both Nigella species under open treatment produced higher yield compared to other pollination treatments.
\end{abstract}

Key-words: Nigella sativa, Nigella damascena, pollination, Black cumin, emasculation.

\section{Introduction}

Nigella L. (Ranunculaceae) includes about 20 species such as (Nigella sativa L., Nigella damascena L., and Nigella arvensis L.). They are widely distributed in Mediterranean regions and West Asia (Hegnauer, 1973). Nigella species consumption has increased during last few years especially in Middle East countries; therefore Nigella appears to be potential multi-purpose crops of possible interest (Riaz et al., 1996). Nigella sativa and Nigella damascena are herbaceous plant of annual growth. Both Nigella species have determinate flowers, producing hermaphrodite flowers which characterized by the presence of nectariferous petals and the an- droecium comprises a large number of stamens. While the gynoecium is composed of a variable number of multi-ovule carpels, developing into a follicle after pollination, with single fruits partially connected to form a capsule-like structure with single fruits. Nigella seeds are small, rough surface and an oily white interior (Zohary, 1983).

The reduction in flower size and other characters correlated with flower size, plant height and leaf size may be an adaptive response to drought or low pollinator abundance (Strid, 1969; Andersson, 1997; 2003). Pollination plays an important role in flowering plant reproduction and fruit set for plant communities (Cor-

\footnotetext{
* Corresponding Author: Tel.: 0096279 5576112; Fax: 0096264 772846. E-mail address: zaitoun@bau.edu.jo;
} zait2010@yahoo.com. 
bet et al., 1991; Buchmann and Nabhan, 1996). The reproductive system of Nigella plants is self-pollination with some extent of cross pollination (McGregor, 1976; Elmer, 2004). Moreover, Irregular of yield is a common problem in seed set of Nigella cultivated under semiarid conditions, the variations in crop production have been related to pollination failure (Wilcock and Neiland, 2002) or drought effect (Strid, 1969). Some researchers reported that the bees is the main pollinator to most plant flowers in natural and semi-natural condition during flowering stage (Richards, 1986; Buchmann and Nabhan, 1996) and sometimes flies and butterflies (Schneider et al., 1994). The main Nigella flower pollinators were honeybees (Ricciardelli and Persano, 1981; Weber, 1992) as well as bumble-bees (Bombus lucorum, Bombus lapidarius), wasps (Polistes dominulus, Eumenes pedunculatus, Cerceris arenaria, Philanthus triangulum and Ammophila sabulosa), Halictus sp., Chrysis sp. and Lasioglossum sp. are major flower visitors in Austria (Weber, 1992; 1995). Colletes punctatus and Epeolus fasciatus in Hungarian (Weber, 1993). The roles of insects in the pollination of Nigella and pollination requirements are not yet evaluated. The main objectives from this study were to identify the bee visitors of both Nigella species (Nigella sativa L., Nigella damascena L.) and the pollination requirement of Nigella flowers grown under semiarid conditions.

\section{Materials and methods}

\section{Site description}

This experiment was careered out during the 2005 growing season in the campus of Jordan University of Science and Technology (JUST),

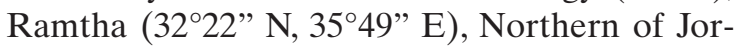
dan. This area characterized by semiarid Mediterranean climate with of mild rainy (200-250 $\mathrm{mm}$ ) winters and dry hot summers. The soils used were shallow rocky silt clays.

\section{Plant materials}

The seeds were brought from Plant Production Department, Faculty of Agriculture, Jordan University of Science and Technology, Jordan. Seeds of both $N$. sativa and $N$. damascena were planted on the $10^{\text {th }}$ of March 2005 by hand at a common rate. Seeds were sown at $15 \mathrm{~cm}$ spaced be- tween plants within the row and one meter spaced between replication. Granular fertilizers DAP (Diammonium phosphate 18\% N and 46\% $\mathrm{P} 2 \mathrm{O} 5)$ was added to the soil before planting at a rate of $100 \mathrm{~kg} \mathrm{ha}^{-1}$. Plants were planted under rainy condition but to prevent effect of drought on crop during growth plants were irrigated by drip irrigation to maintain $70-90 \%$ from field capacity (Rowarth et al., 1997) dependent on tensiometers. Weeds were controlled by hand, when needed.

\section{Pollination studies}

Five pollination treatments, open pollination (natural pollination by insects and wind), cross pollinated of caged flowers (emasculated flowers hand pollinated with pollen grains from other plant), self pollinated of caged flowers (emasculated flowers hand pollinated with pollen grains the same flower), open pollinated emasculated flowers (plant with emasculated flowers accessible to naturally occurring insect pollinators) and control or cover pollination (prevent pollination by insects by using a net bag with 1x1-mm mesh size) were used in this experiment. Two Nigella species; $N$. sativa and $N$. damascena were used in this experiment. To compare between two species the plant height, branch per plant, number of champers, capsules per plant, days to flowering and days to harvesting where recorded during the experiment. After maturation of seeds plants were removed from soil, cleaned and seeds manually separated by hand and the number of seeds per capsule, number of seeds per plant and total weight of seeds per plants were recorded.

\section{Bee visitors}

Bees were caught by a national park net by sweep netting the bees that had visited the flowers in the transect area. Insect visitors were collected for one day every three days interval between 9:00 and 16:00 during the entire flowering period from May to June. The collected specimens were kept in special storage insect boxes. Voucher specimens of bees are kept in the Laboratory of Beekeeping, Faculty of Agriculture, Jordan University of Science and Technology.

\section{Statistical analysis}

The experiment was planed as a split-plot of randomized completely block design (RCBD) 
with twelve replicates. Data were analyzed by analysis of variance (ANOVA) using SAS program. Differences between treatments means was separated according to least significant difference LSD at 0.05 probability level.

\section{Results and discussion}

Bee visitors

Nigella flowers of both species have pollen and nectar but they were non attractive to bees. During the flowering period, a total of 675 bees were visited Nigella flowers. 255 bees were visited $N$. sativa flowers, while 420 bees were visited $N$. damascena flowers as shown in Figure (1). All collected insect specimens were Hymenoptera insects including Apis mellifera, Andrena spp., Lasioglossum pauxillum, Anthophora albigena, Polistes dominulus, Bombus terrestris, Eucera nigrescens, Anthidium undulatum and Heriades syriaca). $66.8 \%$ of bee insects were honeybees, followed by Anthophora albigena (7\%) and Andrena sp. (6.9\%). N. damascena flowers were more attractive in bee numbers (35.7\% and $64.3 \%$ were visited $N$. sativa and $N$. damascena flowers respectively), and in diversity that $N$. sativa were visited by seven different bee species, while $N$. damascena flowers visited by nine species. The rest of flower visitors were shared in lows numbers which means that their contribution to pollination of the Nigella flowers seems to be small and unreliable. The un attractively of Nigella flowers to insect visitors could be attributed to quantity and quality of pollen and nectar in the flowers or the flowering of more suitable plant competitors at the same date of Nigella flower opening. Furthermore, $N$. damascena flowers attracted more bee numbers and species may be as a result of longer flowering period over $N$. sativa and delayed of flower opening which coincide with the drying of different wild plant species which consider a plant competitor in the field. These results are in agreement with the observations made by Ricciardelli and Persano (1981); Weber, 1992 and Engels et al. (1994), that Apis mellifera workers were the main flower visitor of Nigella flowers. Furthermore, other bee species such as Bombus lucorum, Bombus lapidaries, Polistes dominulus, Eumenes pedunculatus, Cerceris arenaria, Philanthus triangulum, Am-

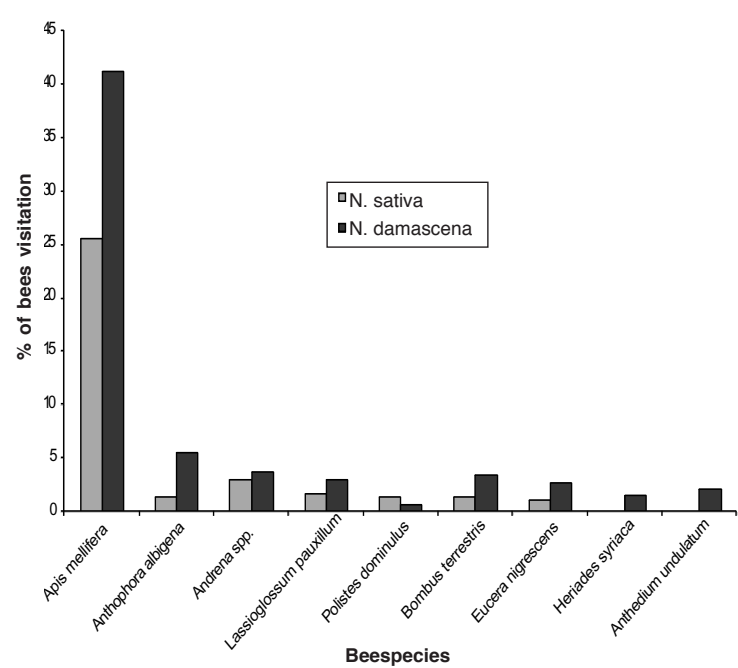

Figure 1. Diversity and visitation frequency of $N$. sativa and $N$. damascena grown under semiarid conditions.

mophila sabulosa, Halictus sp., Chrysis sp., Lasioglossum sp., Colletes punctatus and Epeolus fasciatus were major flower visitors in Austria and Hungarian (Weber, 1992; 1993; 1995).

The number of visitors is very important in pollination due to increase effective pollinator (Primack and Silander, 1975; Herrera, 1989; Proctor et al., 1996). The unattractively of Nigella flowers to wild bees may be attributed to several factors such as the presence of other floral resources. In the present study, $N$. sativa flowering coincided with that of other species such as Centaurea syriaca and Sinapis alba and S. arvensis which are important for apiculture in Jordan due to their abundant nectar and the large floral patches they form throughout the area (Zaitoun and Vorwohl, 2003). Honeybees are important pollinator known in other crops such as pear (Pyrus spp.) orchards surrounded by Sinapis alba and Stellaria spp. this results was found by Stephen (1958). A similar result was foun in plum (Prunus spp.) and almonds (Amygdalus communis) orchards growing next to Sinapis alba (Vansell, 1952; Eisikowitch and Lupo, 1989).

\section{Morphological characteristics}

Table 1 shows the morphological characteristics of $N$. sativa and $N$. damascena grown under semiarid conditions. $N$. damascena produced on average significantly $(\mathrm{P} \leq 0.05)$ higher plant $(50$ $\mathrm{cm})$ and more number of branches per plant (20.7) compared to $N$. sativa (35 $\mathrm{cm}$ height and 
Table 1. Morphological characteristics of N. sativa and N. damascena grown under semiarid conditions.

\begin{tabular}{lcccccc}
\hline Species & \multicolumn{7}{c}{ Parameter } \\
\cline { 2 - 7 } & $\begin{array}{c}\text { Plant height } \\
(\mathrm{cm})\end{array}$ & $\begin{array}{c}\text { Branch per } \\
\text { plant }\end{array}$ & $\begin{array}{c}\text { No. of } \\
\text { champers }\end{array}$ & $\begin{array}{c}\text { Capsules per } \\
\text { plant }\end{array}$ & $\begin{array}{c}\text { Days to } \\
\text { flowering }\end{array}$ & $\begin{array}{c}\text { Days to } \\
\text { harvesting }\end{array}$ \\
\hline N. sativa & 35 & 9.5 & 5.3 & 8.5 & 50 & 88 \\
$N$. damascena & 50 & 20.7 & 5.5 & 18 & 68 & 105 \\
\hline LSD (0.05) & 3.7 & 4.5 & 0.31 & 4.3 & 2.9 & 3.0 \\
\hline
\end{tabular}

9.5 branches per plant). Moreover, $N$. damascena produced significantly more seed yield per plant and total weight (1386 and $5.6 \mathrm{gm}$ ) than $N$. sativa (597 and 2.5 gm per plant). $N$. damascena produced significantly higher number of capsules per plant (18) than $N$. sativa (8.5). Although, the exceptional character was Number of chambers per capsule, that $N$ sativa and $N$. damascena produced on average 5 champers per capsule. On the other hand, days to flowering and days to harvesting were significant difference between two species at $(\mathrm{P} \leq 0.05)$. The mean number of days from sowing to start flowering was 50 and 68 days for $N$. sativa and $N$. damascena respectively. This period was extended to 88 and 105 days to harvesting $N$. sati$v a$ and $N$. damascena seeds respectively. These results were in agreement with Filippo (2002), who reported that the $N$. damascena longer, more Branch number per plant, capsules per plant, seed yield, total yield, early flowering and harvesting than $N$. sativa grown under Mediterranean condition.

\section{Yield production}

Table 2 shows the effects of pollination treatments on number of ovaries, seeds per capsules, seed set percentage, seeds per plant and total seed weight for two species. There is no interaction between Nigella species and pollination treatments for all yield parameter. There are significant difference in number of ovaries between species at $(\mathrm{P} \leq 0.05)$, but not between treatments. $N$. damascena had higher number of ovaries than $N$. sativa which caused an increase in the total seed number of $N$. damascena as compared to $N$. sativa. Significantly differences at $(\mathrm{P} \leq 0.05)$ in seeds number per capsule, total seed number and weight per plant were found among species and pollination treatments. $N$. damascena had greater number of seeds per capsule than $N$. sativa under all pollination treatments. Open pollinated treatment pro- duced significantly more seeds set per capsule than other treatments in both species. In the present study the high seed set obtained may be attributed to the $N$. damascena had higher number of branches per plant than N. sativa and the mild spring conditions and suitable daily temperature which favored the activity of potential insect pollinators. The increased seed set and yield under open-pollinated conditions have been reported in different crops such broad beans (Frusciante and Monti, 1980; Stoddard and Bond, 1987), Lupines (Williams, 1987), Alfalfa (Robinson et al., 1989), Red clover (Osborne et al., 1991) and different other crops listed by McGregor (1976) and Free (1993). These results also indicated that wind did not play an important role for pollination success since the emasculated open pollinated treatment resulted in non seed production compared with the control. Seed-set success is influenced not only by pollination success but also by post-pollination processes such as pollen germination activity, pollen tube growth, and development of fertilized seeds (Stephenson, 1981; Lee, 1988). Variations in the quality of pollen received by flowers have been related to directional movement of pollinators, to the order of development of flowers, (Wyatt, 1982; Nilsson, 1983; Berry and Calvo, 1991; Brunet and Charlesworth, 1995; Brunet, 1996) and to insufficient pollen receipt (Lee, 1988; Berry and Calvo, 1991; Brunet and Chalesworth, 1995). Total seed weight was greatly affected by Nigella species and treatments at $(\mathrm{P} \leq 0.05)$. N. damascena had significantly greater seed weight than $N$. sativa as a result of the genetic high number of capsules per plant and the high number of seeds per capsule under all pollinated treatment. The increased seed numbers in open pollinated flowers resulted in the highest total seeds weight than other treatments in both species. Similar results have been obtained with many other species (Holtsford, 
Table 2. Effects of pollination treatments on number of ovaries, seeds per capsule, seed set \%, seeds per plant and total seed weight (g) of $N$. sativa and $N$. damascena grown under semiarid conditions.

\begin{tabular}{|c|c|c|c|c|c|c|}
\hline \multirow[t]{2}{*}{ Treatments } & \multirow[b]{2}{*}{ Species } & \multicolumn{5}{|c|}{ Parameter } \\
\hline & & $\begin{array}{c}\text { Number of } \\
\text { ovaries }\end{array}$ & $\begin{array}{l}\text { Seeds per } \\
\text { capsule }\end{array}$ & $\begin{array}{c}\text { Seed set } \\
\%\end{array}$ & $\begin{array}{l}\text { Seeds } \\
\text { per plant }\end{array}$ & $\begin{array}{c}\text { Total } \\
\text { weight }(\mathrm{g})\end{array}$ \\
\hline \multirow[t]{2}{*}{ Open pollinated } & N. sativa & 85 & 76 & 89 & 986 & 3.4 \\
\hline & N. damascena & 140 & 135 & 96 & 2622 & 9.2 \\
\hline \multirow[t]{2}{*}{ Cross pollinated } & $N$. sativa & 84 & 61 & 73 & 579 & 2.6 \\
\hline & N. damascena & 139 & 103 & 74 & 1141 & 5.9 \\
\hline \multirow[t]{2}{*}{ Self pollinated } & N. sativa & 83 & 51 & 61 & 569 & 2.7 \\
\hline & N. damascena & 139 & 88 & 63 & 1121 & 5.4 \\
\hline \multirow[t]{2}{*}{ Emasculated } & N. sativa & 84 & 37 & 44 & 150 & 1.0 \\
\hline & N. damascena & 140 & 69 & 49 & 732 & 2.5 \\
\hline \multirow[t]{2}{*}{ Covered/Control } & N. sativa & 85 & 50 & 59 & 701 & 2.4 \\
\hline & N. damascena & 140 & 87 & 62 & 1314 & 4.7 \\
\hline \multirow[t]{7}{*}{ Main Effects } & N. sativa & 84 & 55 & 63 & 597 & 2.5 \\
\hline & N. damascena & 140 & 97 & 69 & 1386 & 5.6 \\
\hline & Open pollinated & 113 & 105 & 93 & 1804 & 6.3 \\
\hline & Cross pollinated & 112 & 82 & 73 & 860 & 4.2 \\
\hline & Self pollinated & 109 & 70 & 64 & 845 & 4.1 \\
\hline & Emasculated & 113 & 53 & 47 & 441 & 1.8 \\
\hline & Covered/Control & 113 & 69 & 61 & 1008 & 3.6 \\
\hline $\operatorname{LSD}^{1}(0.05)$ & & 7.9 & 7.4 & 6.8 & 274 & 0.82 \\
\hline $\operatorname{LSD}^{2}(0.05)$ & & 6.9 & 9.1 & 6.5 & 376 & 1.2 \\
\hline $\operatorname{LSD}^{3}(0.05)$ & & $\ddagger \mathrm{ns}$ & ns & n.s & $\mathrm{n} . \mathrm{s}$ & n.s \\
\hline
\end{tabular}

$\dagger^{1,2}$, Fisher's Least Significantly Difference to compare accession means, treatment means, or treatment $\mathrm{x}$ accession interaction; $\ddagger$ ns: not statistically significant.

1985; Devlin, 1989; Karoly, 1992; Brunet, 1996).

In summary, both $N$. sativa and $N$. damasce$n a$ are adapted to grow under semiarid conditions with different productivity rate and were visited by a diversity of insect pollinators. In spite of $N$. damascena produced more yield than $N$. sativa under our experimental conditions; it delayed in flowering and maturation which may expose it to drought conditions prevailed in the area.

\section{References}

Andersson S. 1997. Genetic constraints on phenotypic evolution in Nigella (Ranunculaceae). Biological Journal of the Linnean Society, 62:519-532.

Andersson S. 2003. Sex-allocation trade-offs in Nigella sativa (Ranunculaceae) examined with flower manipulation experiments. Evolutionary Ecology, 17:125-138.

Berry P.E., Calvo R.N. 1991. Pollinator limitation and position dependent fruit set in the high Andean orchid Myrosmodescochleare (Orchidaceae). Plant Systematics and Evolution, 174:93-101.

Brunet J. 1996. Male reproductive success and variation in fruit and seed set in Aquilegia caerulea (Ranunculaceae). Ecology, 77:2458-2471.
Brunet J., Charlesworth D. 1995. Floral sex allocation in sequentially blooming plants. Evolution, 49:70-79.

Buchmann S.L., Nabhan G.P. 1996. The Forgotten Pollinators. Island Press, Washington, DC.

Corbet S.A., Williams I.H., Osborne J. 1991. Bees and the pollination of crops and wild flowers in the European community. Bee World, 72:47-59.

Devlin B. 1989. Components of seed and pollen yield of Lobelia cardinalis: variation and correlations. American Journal of Botany, 76:204-214.

Eisikowitch D., Lupo A. 1989. Wild flowers as competitors for pollinators in almond orchards. Alon Hanotea, 12:1307-1312.

Ellmer M., Andersson S. 2004. Inbreeding depression in Nigella degenii (Ranunculaceae): Fitness components compared with morphological and phenological characters. Int. J. Plant Sci., 165:1055-1061.

Engels W., Schulz U., Radle M. 1994. Use of the Tübingen mix for bee pasture in Germany. In: Matheson A. (ed.): Forage for Bees in an Agricultural Landscape. International Bee Research Association, Cardiff, UK, 57-65.

Filippo L., Alessandro M., Antonio F. 2002. Seed yield, yield components, oil content and essential oil content and composition of Nigella sativa L. and Nigella damascena L. Industrial Crops and Products, 15:59-69.

Free J.B. 1993. Insect pollination of crops. $2^{\text {nd }}$ ed. London, Academic press. 
Frusciante L., Monti L.M. 1980. Direct and indirect effects of insect pollination on the yield of field beans (Vicia faba L.). Z. Pflanzenzücht, 84:323-328.

Hegnauer R. 1973. Chemotaxonomie der Pflanzen. Birkhauser Verlag, Basel, Stutgart, 43.

Herrera C.M. 1989 Pollinator abundance, morphology, and flower visitation rate: analysis of the "quantity" component in a plant-pollinator system. Oecologia, 80:241-248.

Holtsford T.P. 1985. Nonfruiting hermaphroditic flowers of Calochortus leichtlinii (Liliaceae): potential reproductive functions. American Journal of Botany, 72:1687-1694.

Karol Y.K. 1992. Pollinator limitation in the facultatively auto-gamous annual, Lupinus nanus (Leguminosae). American Journal of Botany, 79:49-56.

Lee T.D. 1988. Patterns of fruit and seed production. In: Lovett Doust J., Lovett Doust L. (eds.): Plant reproductive ecology, patterns and strategies, 179-202. Oxford University Press, New York, New York, USA.

McGregor S.E. 1976. Insect pollination of cultivated crop plants. Agriculture Handbook, 496, U.S. Gov. Print. Office, Washington, DC.

Nilsson L.A. 1983. Anthecology of Orchis mascula (Orchidaceae). Nordic Journal of Botany, 3:157-179.

Osborne J.L., Williams I.H., Corbet S.A. 1991. Bees, Pollination and habitat change in the European Community. Bee World, 72:99-116.

Primack R.B., Silander J.A. 1975. Measuring the relative importance of different pollinators to plants. Nature, 255:143-144.

Proctor M., Yey P., Lack A. 1996. The natural history of pollination. Timber Press, Portland, Oregon, USA, pp. 487.

Riaz M., Syed M., Chaudhary F.M. 1996. Chemistry of the medicinal plants of the genus Nigella. Hamdard Medicus, 39, 2:40-45.

Ricciardelli D.G., Persano Oddo L. 1981. Flora apistica italiana. Istituto sperimentale zoologia agraria and Federazione italiana apicoltori, Interstampa, Rome.

Ricciardelli D.G., Persano O.L. 1981. Flora apistica italiana. Istituto sperimentale zoologia agraria and Federazione italiana apicoltori. Interstampa, Rome.

Richards A.J. 1986. Plant Breeding Systems. Chapman Hall, New York, USA.

Robinson W.S., Nowogrodzki R., Morse R.A. 1989. The value of honeybees as pollinators of U.S. crops. Am. Bee. J., 129:411-423, 477-487.
Rowath J.S., Chapman H.M., Novis P., Rolston M.P. 1997. Water stress and seed yield in perennial ryegrass grown in pots. J. Appl. Seed Prod, 15:89-92.

Schneider Ch., Sukopp U., Sukopp H. 1994. Biologischökologische Grundlagen des chutzes gefährdeter Segetalpflanzen. Bundesamt für Naturschutz, BonnBad Godesberg.

Stephen W.P. 1958. Pear pollination studies in Oregon. Bull Ore. Agric. Exp, Stn, 43.

Stephenson A.G. 1981. Flower and fruit abortion: proximate causes and ultimate functions. Annual Review of Ecology and Systematic, 12:253-279.

Stoddard F.L., Bond D.A. 1987. The pollination requirements of the faba beans. Bee World, 68:144-152.

Strid A. 1969. Evolutionary trends in the breeding system of Nigella (Ranunculaceae). Bot. Not., 122:380396.

Vansell G.H. 1952. Variations in nectar and pollen sources affect bee activity. Amer. Bee J., 92:325-326.

Weber A. 1992. Nigella arvensis (Ranunculaceae) Blüte und Bestäubung. Film C 2238 des ÖWF. Wien. Österr. Bundesinst. f. d. Wissenschaftl. Film. Begleitpublikation in: Wiss. Film (Wien), 44:53-60.

Weber A. 1993. Struktur, Antheseverlauf und Bestäubung der Blüte von Nigella arvensis (Ranunculaceae). Verhandl. Zool.-Bot. Ges. Österr., 130:99-125.

Weber A. 1995. Pollination of Nigella arvensis (Ranunculaceae) (film presentation). Plant Syst. Evol., Suppl., 9:325-326.

Wilcock C., Neiland R. 2002. Pollination failure in plants: why it happens and when it matters. Trends in Plant Science, 7, 6:270-277.

Williams I.H. 1987. The pollination of Lupins. Bee world, 68:10-16.

Wyatt R. 1980. The reproductive biology of Asclepias tuberose I. Flower number, arrangement, and fruit set. New Phytologist, 85:119-131.

Zaitoun S., Vorwohl G. 2003. Major Pollen Plant Species in Relation to Honeybees Activity in the Jordanian desert Area. International Journal of Agriculture and Biology, 5, 4:411-415.

Zohary M. 1983. The genus Nigella (Ranunculaceae) a taxonomic revision. Plant Systematics and Evolution, 142:71-107. 